African J. Biol. Sci., 17 (1): 205-219 (2021)

ISSN 1687-4870

www.ajbs.journals.ekb.eg

e- ISSN 2314-5501 (online)

E.mail: aasdjournal@yahoo.com

\title{
Curcumin (Curcuma longa) and quercetin nanoparticles as antimicrobial and anticancer agents
}

\author{
Safaa M. Faid \\ Department of Home Economics, Faculty of Specific Education, Ain Shams Univ., Cairo, Egypt \\ Email: dr_safaa2010@yahoo.com
}

Received: August 2, 2021; Accepted: September1, 2021; Available online: September 3, 2021

This study was achieved to evaluate the anticancer and antibacteria activities of curcumin and quercetin naoparticles. Also, the chemical, minerals content, total phenolic, total flavonoids compounds, and DPPH radical scavenging activity of curcumin were determined. The results indicated that the curcumin contains high amounts of protein and total carbohydrates, in addition to lower levels of ash, crude fiber, and total lipids. The total phenolic and flavonoids and the DPPH radical scavenging activity were estimated at different concentrations of curcumin extract $(10,20,30,40$, and $50 \mu \mathrm{g} / \mathrm{ml}$ ) with different solvents (ethanol, ethyl acetate, chloroform, and water). The results showed that the ethanol extract had high amounts from total phenolic and flavonoids and the highest DPPH radical scavenging activity followed by ethyl acetate, chloroform, and water.

The effect of the prepared nanoparticles of curcumin and quercetin extracts were studied as preventive to MCF-7 human cancer breast and as antibacterial for Streptococcus aures, Streptococcus penoenumoia and Bacillus substilis (Gram-positive bacteria), Escherichia coli, Salmonella typhimrium and Pseudomonas aeruginosa (Gram-negative bacteria). The results showed that the curcumin and quercetin nanoparticles extracts were significantly increased cell cytotoxicity, from the minimum to maximum concentrations ranging from 6.25 to $100 \mu \mathrm{g} / \mathrm{ml}$ which inhibit these cells from 3.21 to $87.53 \%$ using nanoparticles of curcumin and 40.34 to $73.93 \%$ by quercetin. The effect of curcumin and quercetin nanoparticles on gram-positive and negative bacteria showed that the highest inhibition zone in gram-positive bacteria and gramnegative bacteria was at $100 \mu \mathrm{g}$.

From the current results, it could be indicated that the curcumin and quercetin nanoparticles contain high amounts from nutrition factors; polyphenolics compounds, and have antioxidant activity, and DPPH scavenging radicals. In addition, they gave the best results as anticancer and antibacterial agents. Therefore, the bioactive compounds found in these natural compounds can delay MCF-7 breast cancer cell lines.

Key words: Curcumin, quercetin nanoparticles, antimicrobial, anticancer.

\section{INTRODUCTION}

Curcumin has received high attention as an antioxidant, anti-inflammatory, and anticancer agent (Tomeh et al., 2019). It is a polyphenol and natural antioxidant. Turmeric powder has contained $77 \%$ curcumin; it is soluble in acetone, methanol, and ethanol (Alves et al., 2019). It Curcumin is a yellow crystalline hydrophobic polyphenol and it is utilized as a traditional medicine against chronic heart diseases, and other different kinds of diseases (Gupta $e t$ al., 2013). 


\section{Safaa M. Faid}

The mechanisms of action of curcumin appear as anticancer activity includes apoptosis and prevention of reproduction and forcibly put an end to a variety of cellular signaling pathways (Kunnumakkara et al., 2017). Curcumin antitumor activity on breast cancer, lung cancer, etc, indicated its capability to multiple cancer cell lines. Despite all the above characteristics utilize of curcumin, its use is limited due to its low solubility in water which resulting in weakly oral bioavailability (Nagahama et al., 2016).

Breast cancer has shown the leading reason of death in women despite lumpectomy, radiotherapy, and chemotherapy. It has been found that the rate of breast cancer remains high (Ananthakrishnan et al., 2012). Therefore, more efficient treatment strategies are still needed. In a research of human breast epithelial cells MCF-10A and breast cancer MCF-7 cells, a significant decrease in telomerase activity was noticed as a result of curcumin therapy in a concentrationdependent manner that was associated with curcumin but not through the pathway of mRNA (Ramachandran et al., 2002). Bachmeier et al. (2007) studied the breast cancer cell lines and confirmed the ability of curcumin to down regulate to an antiproliferative influence. Furthermore, curcumin suppressed breast tumors by overexpressing the p53 gene and reducing the levels of ki-67 antigen (Moghtaderi et al., 2017). Another research on MDA-MB231 cells has shown that curcumin also inhibits inflammatory cytokines CXCL 1and 2. Inhibition of inflammatory cytokines by curcumin inhibits the expression of a series of tumor-promoting genes such as CXCR4 chemoreceptors (Bachmeier et al., 2008). Dimethyl curcumin has been influential against breast cancer via inhibiting several types of steroid receptors (Verderio et al., 2014).

Polymeric nanoparticles were prepared and used to encapsulate, protect, and release two bioactive flavonoid molecules, quercetin and catechin. Thus it showed that both flavonoids were successfully encapsulated in a noncrystalline state within the nanoparticles matrix. Therefore that nanoparticles could be suitable for the encapsulation of bioactive compounds (such as flavonoids and vitamins) and to release them in acidic environments, such as the stomach of some food products. These findings could also be useful for the design and fabrication of polymeric nanoparticles for the targeted release of these compounds within the stomach for thetreatment of local diseases or to release them in acidic food products, producing novel functional foods (Pool et al., 2012).

Therefore, this study showed that the effect of curcumin and quercetin in the prevention and the treatment of cancer breast, and they use as antimicrobial agents. Also, the objective of this investigation is to evaluate the antioxidant possibility for these natural compounds.

\section{MATERIALS_AND METHODS Materials \\ Quercetin and curcumin were purchased from Sigma-Aldrich, Singapore, and used as received. All reagents used were of technical grade. The absolute ethanol}




\section{Curcumin (Curcuma longa) and quercetin nanoparticles as antimicrobial and anticancer agents}

(99.5-99.8\%) was obtained from J.T. Baker (Avantor Performance materials, Phillipsburg, NJ). Poly (D,L-lactic-coglycolic acid) (PLGA) (Resomer R503H; MW 35-40 kDa), poly (vinyl alcohol) (PVA) (MW 30-70 kDa) were obtained from were purchased from Sigma- Aldrich (St. Louis, MO, USA). Gallic acid, catechin, 1,1- diphenyl-2-picrylhydrazyl radical (DPPH), and 2,4,6-tris (2- pyridyl)-1,3,5triazine (TPTZ) were purchased from Sigma- Aldrich (St. Louis, MO, USA). Folin-Ciocalteu's phenol reagent, and ferrous sulfate heptahydrate (FeSO4 7H2O) were purchased from Merck Co. (Darmstadt, Germany). All of the chemicals and reagents used in this study were of analytical grade.

Butelate hydroxyl anisole (BHT) as synthetic antioxidant were obtained from Sigma-Aldrich (Pozna' n, Poland),

\section{Methods \\ Chemical composition and minerals content of curcumin}

Chemical composition as moisture, crude protein, ether extract, ash, crude fiber, and carbohydrates was determined by using the methods of the AOAC (2012). Minerals content $(\mathrm{Na}, \mathrm{Ca}$, and $\mathrm{K})$ were determined in the diluted solution of ash samples by using an emission flame photometer (Model Corning 410). The other minerals (Zn, P, Fe, and $\mathrm{Mg}$ ) were determined by the Atomic absorption spectrophotometer (Perkin Elmer Instrument Model 2380) according to the method of AOAC (2012).

Preparation of curcumin and quercetin extracts

Dried powder of each of curcumin or quercetin $(10 \mathrm{~g})$ was dispensed in $100 \mathrm{ml}$ for each of distilled water, ethanol, ethyl acetate and chloroform, overnight at room temperature using shaker. The mixture was filtered through Whitman No 1 filter paper and the extraction step was repeated twice. The filtrate was then concentrated to dryness at $40{ }^{\circ} \mathrm{C}$ in a rotary evaporator. The crude extracts were stored in a refrigerator until further analysis according to Kang (2015).

\section{Estimation of total phenolic acids and flavonoids compounds of curcumin and quercetin}

The total phenolic content in the mulberry extract was measured using the method of Qawasmeh et al. (2012) with Folin-Ciocalteu reagent. The UV reading was measured at $760 \mathrm{~nm}$. Gallic acid was used as standard $(1 \mathrm{mg} / \mathrm{ml})$ and the results were expressed as gallic acid equivalent (GAE mg/100g of dry weight).

The total flavonoids content was determined by the method of Eghdami and Sadeghi (2010). The absorbance was measured against a blank solution at $510 \mathrm{~nm}$ and the total flavonoids content was expressed in terms of milligrams of quercetin equivalent (mg QE /100g DW).

\section{Antioxidant activity}

DPPH• (1,1-Diphenyl-2-picrylhydrazyl) Free radical scavenging assay

Determination of Butyl Hydroxy Toluene $(\mathrm{DPPH})^{\bullet}$ free radical scavenging activity was measured in green banana according to Ravichandran et al. (2012). BHT, Sigma was used as positive control, while the negative control is contained the entire reaction reagent except the extracts. Then the absorbance was measured at 515 $\mathrm{nm}$ against blank. The capacity to scavenge 


\section{Safaa M. Faid}

the DPPH - radical was calculated using the following equation:

DPPH - scavenging effect (Inhibition \%) = [(Ac - As / Ac $) \times 100]$

Where: Ac is the absorbance of the control reaction.

As is the absorbance in the presence of the plant extracts

\section{Preparation of curcumin nanoparticles}

Nanoparticles loaded with curcumin were prepared by a modified emulsiondiffusion-evaporation method, previously reported with Devadasu et al. (2011). Briefly, curcumin (7.5 mg) and Poly (lactide -co- glycolide) acid (PLGA) (50 mg) were dissolved in $2.5 \mathrm{ml}$ of ethyl acetate and stirred at $1,000 \mathrm{rpm}$ for $30 \mathrm{~min}$ under room temperature to obtain a homogeneous solution. Either Polyvinyl alcohol (PVA) (50 mg), used as a stabilizer, was dissolved in $5 \mathrm{ml}$ distilled water. The organic phase containing the active ingredient and PLGA was then added in a drop-wise manner to the stabilizer solution during homogenization. Homogenization was continued for $5 \mathrm{~min}$ at $15,000 \mathrm{rpm}$. After this step, the emulsion was transferred to $20 \mathrm{ml}$ water to facilitate diffusion and was stirred overnight to ensure the complete evaporation of the organic solvent. After the evaporation step was complete, the nanoparticles solution was centrifuged at $15,000 \times \mathrm{g}$ for $15 \mathrm{~min}$ to separate free active ingredient and any unbound stabilizer in the solution. The supernatant was separated and the pellet was redispersed in $20 \mathrm{ml}$ water then the curcumin nanoparticles with PVA.

\section{Preparation of quercetin nanoparticles (QUNPs)}

Quercetin were prepared by adding ethanol to water volume ratio (1:35), fixed flow rate $(10 \mathrm{ml} / \mathrm{min})$ under magnetic stirring (1000 rpm) according to the nano participation technique according to Kakran et al. (2012) and Abd El-Rahmanand and Al-Jameel (2014). Quercetin was dissolved in the solvent (ethanol) at predetermined concentration of $5 \mathrm{mg} / \mathrm{ml}$. The syringe was filled with the prepared solution and secured onto a syringe pump. Drug solution was quickly injected at a fixed flow rate into the anti-solvent (deionized water) of definite volume under magnetic stirring. The QUNPs were filtered and vacuum dried.

\section{Human cell lines}

Potential human cell lines: MCF-7 breast cancer cell lines (human cancer breast) were obtained from VACSERA Tissue Culture Unit and were tested using the method of Gomha et al. (2015).

\section{Antimicrobial activity}

The antimicrobial activity of samples was determined using agar well diffusion method Scott (1989). Ethanol extract from Curcumin and quercetin nanoparticlessize were tested in vitro for their antibacterial activity against Streptococcus aures, Streptococcus penoenumoia and Bacillus substilis (Gram-positive bacteria), Escherichia coli, Salmonella typhimrium and Pseudomonas aeruginosa (Gramnegative bacteria) using nutrient agar medium. Curcumin and quercetin nanoparticles were dissolved in a $70 \%$ ethanol solution. In addition, the curcumin 


\section{Curcumin (Curcuma longa) and quercetin nanoparticles as antimicrobial and anticancer agents}

and quercetin nanoparticles solvent was assayed at concentrations of $25,50,75$, and, $100 \mu \mathrm{g} / \mathrm{ml}$.

\section{Method of testing}

The sterilized media was poured onto the sterilized Petri dishes $(20 \mathrm{ml}$, each Petri dish) and allowed to solidify, in addition, the concentration of different positive and negative bacterial was adjusted as $5 \times 105 \mathrm{CFU} / \mathrm{ml}$. Filter paper wells of 6 $\mathrm{mm}$ diameter were made in the solidified media with the help of a sterile borer. A sterile swab was used to evenly distribute microbial suspension over the surface of solidified media and curcumin nanoparticle extract was added to each filter paper well with the help of a micropipette at different concentrations $25,50,75$, and $100 \mathrm{ug} / \mathrm{ml}$. The plates were incubated at $37^{\circ} \mathrm{C}$ for $24 \mathrm{hrs}$ in case of antibacterial activity. The diameter of the zones of inhibition around each of the wells was taken as a measure of the antibacterial activity. Each experiment was carried out in triplicate and the mean diameter of the inhibition zone was recorded.

\section{Statistical analysis}

Means \pm SD of the results are statistically analyzed using one-way analysis of variance (ANOVA), $p \leq 0.05$ was used to indicate significance. Statistical software (Assistat Version 7.7, Brazil) was used for all statistical analyses according to Silva and Azevedo (2009).
RESULTS AND DISCUSSION Chemical composition and minerals content in curcumin

The result in Table (1) showed that curcumin contains moisture, ash, crude fiber, and total lipids and their percentage were 9.21, 4.32, 6.54, and $3.76 \%$, respectively. In addition, it contains 10.38 $\%$ crude protein and $74.00 \%$ total carbohydrates. This implies curcumin could be a good source of protein and carbohydrates and it was lower in ash, crude fiber, and total lipids. Turmeric had contained a reasonable amount of ash and minerals. The fiber in turmeric removes possible carcinogens from the body and prevents excessive intake of starchy foods, thus may protect against metabolic conditions such as hypercholesterolemia and diabetes (Bamishaiye et. al., 2011).

Ahamefula et al. (2014) found the chemical composition of curcumin from moisture, ash, crude protein, crude fiber, and fat were 8.92, 2.85, 9.42, 4.60, and 6.85, respectively. In addition, turmeric contents often vary with species, locations, and cultivation conditions, while there are significant variations in the constituent of turmeric oil with various cultivars. (Li et al., 2011). In the present study curcumin contains calcium, phosphorus, potassium, iron, magnesium and Sodium $(0.17,0.71$, $0.41,0.03,0.28$ and $0.02 \%$, respectively). Thus, continuous curcumin feeding could be of great significance in maintaining bone strength, muscle contraction and relaxation, lowering blood pressure, and aiding in hemoglobin formation (Kubmarawa et al., 2007). Calcium is a key agent in 


\section{Safaa M. Faid}

maintaining bone strength and absorption of vitamin B12, potassium, and magnesium and is known to lowering blood pressure. Potassium is controlling skeletal muscle contraction and transmission of nerve impulses, and patients with soft bone problems nutrition on diets great in calcium and potassium (Kubmarawa et al., 2007).
The iron content in curcumin extract can aid in the formation of hemoglobin (Latunde dada, 1980) and is therefore recommended for iron shortage anemia. Several minerals are also coenzymes involved in certain biochemical reactions in the body which underlines the significance of the plant in metabolic reactions.

Table (1). Chemical and minerals content in curcumin on dry weight (g/100g)

\begin{tabular}{|c|c|c|c|}
\hline Chemical composition & Curcumin & Minerals content & Curcumin \\
\hline Moisture & $9.21 \pm 0.83$ & Calcium & $0.17 \pm 0.01$ \\
\hline Protein & $10.38 \pm 0.91$ & Phosphorus & $0.41 \pm 0.02$ \\
\hline Total Fat & $1.76 \pm 0.02$ & Magnesium & $0.28 \pm 0.01$ \\
\hline Crude fiber & $6.54 \pm 0.04$ & Potassium & $0.71 \pm 0.81$ \\
\hline Ash content & $4.32 \pm 0.03$ & Iron & $0.03 \pm 0.00$ \\
\hline Total carbohydrates & $77.00 \pm 6.24$ & Sodium & $0.02 \pm 0.00$ \\
\hline
\end{tabular}

Values are mean and SD $(\mathrm{n}=3)$

Total phenolic acids and flavonoids compounds in of curcumin extracts

Total phenolic and flavonoids compounds were determined in curcumin at different extracts (aqueous, ethanol, ethyl acetate and chloroform) and the results are reported in Table (2). From the results, it could be observed that the curcumin ethanol extract had the highest total phenolic and flavonoids compounds by $55.35 \mathrm{mg} / 100$ GAE and $40.12 \mathrm{mg} / 100 \mathrm{QE}$ followed by ethyl acetate $(32.21 \mathrm{mg} / 100 \mathrm{GAE}$ and 25.37 $\mathrm{mg} / 100 \mathrm{QE})$ and chloroform was 25.39 $\mathrm{mg} / 100 \mathrm{GAE}$ and $17.16 \mathrm{mg} / 100 \mathrm{QE}$, respectively. Meanwhile, curcumin aqueous extract had the lowest in total phenolic and flavonoids compounds by $15.69 \mathrm{mg} / 100$ GAE and $10.94 \mathrm{mg} / 100 \mathrm{QE}$, respectively. The results showed that the ethanol extracted from turmeric gives the greatest efficient extraction of total phenolic content and also, followed by ethyl acetate, chloroform, and aqueous. A greater total phenolic content in turmeric extraction with ethanol solvent may be due to the fact that the main phenolic compounds of turmeric had contained a long, non-polar chain of carbon-carbon covalent bonds with a phenolic group attached to the ends (Shen and $\mathrm{Ji}, 2012$ ). The structure allows them to dissolve most freely in ethanol followed by ethyl acetate, chloroform, and partially in water. In addition, curcuminoids are practically insoluble in water, and this explain the low level of total flavonoids in the water extract (Sindhu et al., 2014).

Curcumin acts as controller of epinephrine endogenous oxidation, and it produce free antifungal that is just as potent as superoxide dismutase (Fuertes Ruitón et 


\section{Curcumin (Curcuma longa) and quercetin nanoparticles as antimicrobial and anticancer agents}

al., 2014). Moreover, curcuminoids inhibit lipid oxidation and prevent food degradation due to the fact that it acts as a trap and scavenging free radicals, thus stimulating enzymatic activity, protecting the organism from aging, and rebuilding biological structures (Stanojević et al., 2015).

Table (2). Total phenolic acids and flavonoids compounds in of curcumin extracts

\begin{tabular}{|c|c|c|}
\hline Curcumin Extracts & $\begin{array}{c}\text { Total phenolic acids } \\
\mathrm{mg} / 100 \mathrm{GAE}\end{array}$ & $\begin{array}{c}\text { Total flavonoids compounds } \\
\mathrm{mg} / 100 \mathrm{QE}\end{array}$ \\
\hline Aqueous & $10.69 \pm 0.57^{\mathrm{d}}$ & $6.94 \pm 0.38^{\mathrm{d}}$ \\
\hline Ethanol & $55.35 \pm 2.3 .28^{\mathrm{a}}$ & $40.12 \pm 3.28$ \\
\hline Ethyl acetate & $32.21 \pm 2.63^{\mathrm{b}}$ & $25.37 \pm 1.69^{\mathrm{b}}$ \\
\hline Chloroform & $25.39 \pm 1.58^{\mathrm{s}}$ & $17.16 \pm 0.85^{\mathrm{c}}$ \\
\hline
\end{tabular}

Values are mean and SD $(n=3)$; where: Mean with the same letter are significantly different at $\mathrm{p}<0.05$ levels.

Antioxidant activity of curcumin extracts at different concentrations

The antioxidant activity was estimated by the 1,1-diphenyl-2picrylhydrazyl (DPPH) free radical scavenging activity. The scavenging activity of curcumin extracts at different concentrations and compared with BHT as synthetic antioxidant were determined and the results are tabulated in Table (3). The results indicated that when the concentration of curcumin increased in different extracts the DPPH scavenging activity was increasing. Thus, it could be found that the curcumin extract at $50 \mu \mathrm{g} / \mathrm{ml}$ had the highest scavenging activity in ethanol extract followed by ethyl acetate, chloroform, and aqueous (55.82, 47.28, 43.24, and 40.11\%, respectively). The BHT as the standard antioxidant has the highest DPPH scavenging activity and $\mathrm{IC}_{50}$ value by $62.38 \%$ and $22.35 \mu \mathrm{g} / \mathrm{ml}$. Moreover, the $\mathrm{IC}_{50}$ values in the different extracts (ethanol, ethyl acetate, chloroform, and aqueous) from curcumin were 30.18, 45.95, 55.28, and $80.15 \mu \mathrm{g} / \mathrm{ml}$, respectively. The results indicated that the free radical scavenging activity of curcumin can be due to the presence of high amounts of natural antioxidants with higher reductive capacity. Surojanametakul et al. (2010) found that when the concentration of turmeric increases, the free radicals absorption by DPPH were decreased, and it is elevating sensitivity to radical scavenging. In general, the ethanol extract had contained high amounts of antioxidant characteristics than those in the aqueous extract (Tanvir et al., 2017).

Table (3). DPPH - scavenging activity of curcumin extracts at different concentrations

\begin{tabular}{|c|c|c|c|c|c|c|}
\hline \multirow{2}{*}{ Curcumin Extracts } & \multicolumn{5}{|c|}{ Scavenging activity \% } & \multirow{2}{*}{$\begin{array}{c}\mathrm{IC}_{50} \\
\end{array}$} \\
\cline { 2 - 6 } & $10 \mu \mathrm{g} / \mathrm{ml}$ & $20 \mu \mathrm{g} / \mathrm{ml}$ & $30 \mu \mathrm{g} / \mathrm{ml}$ & $40 \mu \mathrm{g} / \mathrm{ml}$ & $50 \mu \mathrm{g} / \mathrm{ml}$ & \\
\hline Aqueous & $20.15 \pm 1.12^{\mathrm{e}}$ & $22.38 \pm 1.42^{\mathrm{e}}$ & $27.59 \pm 2.28^{\mathrm{e}}$ & $32.91 \pm 2.58^{\mathrm{e}}$ & $40.11 \pm 3.21^{\mathrm{e}}$ & $80.15 \pm 5.11^{\mathrm{a}}$ \\
\hline Ethanol & $40.26 \pm 2.31^{\mathrm{b}}$ & $44.38 \pm 3.38^{\mathrm{b}}$ & $48.49 \pm 4.12^{\mathrm{b}}$ & $51.67 \pm 4.13^{\mathrm{b}}$ & $55.82 \pm 4.17^{\mathrm{b}}$ & $30.18 \pm 2.83^{\mathrm{d}}$ \\
\hline Ethyl acetate & $35.15 \pm 2.83^{\mathrm{c}}$ & $37.27 \pm 3.14^{\mathrm{c}}$ & $41.62 \pm 3.43^{\mathrm{c}}$ & $43.38 \pm 3.635^{\mathrm{c}}$ & $47.28 \pm 4.35^{\mathrm{c}}$ & $45.95 \pm 4.21^{\mathrm{c}}$ \\
\hline Chloroform & $30.38 \pm 2.19^{\mathrm{d}}$ & $35.28 \pm 2.34^{\mathrm{d}}$ & $37.12 \pm 2.46^{\mathrm{d}}$ & $40.29 \pm 3.29^{\mathrm{d}}$ & $43.24 \pm 3.81^{\mathrm{d}}$ & $55.28 \pm 4.78^{\mathrm{b}}$ \\
\hline BHT as standard & $45.29 \pm 3.27^{\mathrm{a}}$ & $47.38 \pm 3.64^{\mathrm{a}}$ & $51.11 \pm 4.14^{\mathrm{a}}$ & $55.29 \pm 4.18^{\mathrm{a}}$ & $62.38 \pm 5.27^{\mathrm{a}}$ & $22.35 \pm 1.56^{\mathrm{e}}$ \\
\hline
\end{tabular}

Values are mean and SD $(n=3)$; where: Mean values with the same letter are significantly different at $\mathrm{p}<0.05$ levels 


\section{Safaa M. Faid}

Effect of curcumin nanoparticles on breast cancer human cell lines

The effect of curcumin nanoparticles extract at different concentrations as anticancer of MCF-7 cancer cell lines was determined and the results are found in Table (4). The results indicated that curcumin nanoparticles extract resulted in a marked elevate in the cytotoxicity of cells, and their inhibition reached to $87.53 \%$ with $100 \mu \mathrm{g} / \mathrm{ml}$ curcmin nanaoparticles. This inhibition can be related to the presence of polyphenolics and flavonoids compounds in curcumin nanoparticles which can exhibit cytotoxic activity against breast carcinoma cells (MCF-7). Phytochemicals are flavonoids that have been brought to a place of great benefit for being a powerful antioxidant with some anticancer effects. Its structure contains a double bond in the Cring and a 4-oxo group, which increases its antioxidant activity (Moskaug et al., 2004).

Also, the present results were consistent with Sundarraj et al. (2012) who found that the bioactive components contained anticancer potential through different mechanisms that included suppression of signaling pathways, induction of death, and cell cycle arrest. Moreover, Swanson (2015) studied the effect of curcumin on MCF-7 tumor cells and normal cells, the results found that the cytotoxic influence of MCF-7 cells was increased than that of normal cells at 50\% curcumin extract concentration, and this cytotoxic influence may be due to the apoptotic influence. At $75 \%$ concentration, the cytotoxic influence was detected with necrosis. Furthermore, excessive production of free radicals will be exacerbated by oxidative damage to proteins, lipids, and DNA, and even lead to cell death.

Table (4). Effect of curcumin nanoparticles on breast cancer human cell lines

\begin{tabular}{|c|c|c|c|}
\hline Concentration $\boldsymbol{\mu g} / \mathbf{~ m l}$ & Viability $\%$ & Inhibitory $\%$ & S.D. $( \pm)$ \\
\hline 0 & 100 & 00 & 00 \\
\hline 6.25 & 96.79 & 3.21 & 0.65 \\
\hline 12.5 & 90.70 & 9.30 & 1.24 \\
\hline 25.0 & 74.59 & 25.05 & 1.86 \\
\hline 50.0 & 63.73 & 36.27 & 2.15 \\
\hline 100.0 & 12.47 & 87.53 & 1.38 \\
\hline
\end{tabular}

\section{Effect of quercetin nanoparticles on breast cancer human cell lines}

The effect of quercetin nanoparticles extract against human breast cancer was estimated and the results are shown in Table (5). It was found that this extract had significant activity against the MCF-7 cell line. The highest inhibition ratio was 76.93\% from quercetin nanoparticles at a concentration $100 \mu \mathrm{g} / \mathrm{ml}$ which may be caused due to their natural antioxidant activity against cancer. The minimum inhibition was observed at concentrations $6.25,12.5$ and $25.0 \mu \mathrm{g} / \mathrm{ml}$ and the inhibition cell lines were $40.34,42.16$, and $48.36 \%$, respectively. This means that the greatest concentration of quercetin nanoparticles 


\section{Curcumin (Curcuma longa) and quercetin nanoparticles as antimicrobial and anticancer agents}

becomes greater in inhibition the growth of MCF-7 cell line.

Quercetin is a powerful flavonoid and it has toxic effects on many types of cancer cells (Srivastava et al., 2016). However, the weak solubility and decreased bioavailability of quercetin have limited their treatment applications (Rauf et al., 2018). Various drug systems, like polymeric nanoparticles, and solid lipid nanoparticles, have been investigated to increase the bioavailability of anticancer agents (Wang et al., 2017). Li et al. (2018) demonstrated that the quercetin nanoparticles are influential in decreasing the cell population and viability of MCF-7 cells through growth inhibition and induction of cell death.

Table (5): Effect of quercetin nanoparticles on breast cancer human cell lines

\begin{tabular}{|c|c|c|c|}
\hline Concentration $\boldsymbol{\mu g} / \mathbf{m l}$ & Viability \% & Inhibitory \% & S.D. $( \pm)$ \\
\hline 0 & 100 & 00 & 00 \\
\hline 6.25 & 59.66 & 40.34 & 3.15 \\
\hline 12.5 & 57.84 & 42.16 & 2.97 \\
\hline 25.0 & 51.64 & 48.36 & 2.39 \\
\hline 50.0 & 41.54 & 58.46 & 3.49 \\
\hline 100.0 & 23.07 & 76.93 & 1.28 \\
\hline
\end{tabular}

\section{Curcumin and Quercetin nanoparticles as antimicrobial agent}

Antibacterial activity was studied with the ethanol extract from curcumin and quercetin nanoparticles at different concentrations $(25,50,75$, and $100 \mu \mathrm{g} / \mathrm{ml})$, as well as, agar well diffusion method was used to determine the zone of inhibition of gram-positive and gram-negative bacterial growth, and the results are reported in Tables (6 and 7).

The results in Table (6) indicated that the curcumin extract was gradually inhibiting zone from concentration $25 \mu \mathrm{g}$ to $100 \mu \mathrm{g}$ in gram-positive and gram-negative. In addition, the highest inhibition zone in gram-positive bacteria was Bacillus subtitles, Streptococcus aureus, and Streptococcus penoenumoia. Whilst, in gram-negative bacteria the highest inhibition zone was Escherichia coli and Salmonella typhimurium. Also, the curcumin nanoparticles extract at $100 \mu \mathrm{g}$ had not detected effect on Salmonella typhimrium. The ethanol extract of curcumin showed considerable inhibitory effects against Escherichia coli, Streptococcus, Staphylococcus, Bacillus cereus, Micrococcus, Pseudomonas, Aspergillus, and Penicillium at a final concentration of $20 \mathrm{mg} / \mathrm{ml}$. Ahamefula et al. (2014) found that the zone of inhibition shown by the plant extracts against the tested organisms ranged from 7.0 to $20.0 \mathrm{~mm}$. Shagufta et al. (2010) observed that curcumin at different concentrations has significant inhibitory activities against all tested bacterial strains. The mechanism of the antibacterial activity of curcumin seems to differ depending on the strain. In the current study, the curcumin 


\section{Safaa M. Faid}

nanoparticles showed stronger antibacterial activity against Escherichia coli which was similar to the observation of Basak et al., (2018).

Table (6). Curcumin nanoparticles as antimicrobial agent

\begin{tabular}{|c|c|c|c|c|}
\hline \multicolumn{5}{|c|}{ Concentration $(\mu \mathrm{L})$} \\
\hline & 25 & 50 & 75 & 100 \\
\hline \multicolumn{5}{|l|}{ Gram-positive (mm) } \\
\hline Streptococcus aures & $3.5 \pm 0.12$ & $9.0 \pm 0.73$ & $15.0 \pm 1.25$ & $39.5 \pm 2.72$ \\
\hline Streptococcus penoenumoia & $8.8 \pm 0.73$ & $13.0 \pm 1.02$ & $24.3 \pm 1.87$ & $38.9 \pm 3.12$ \\
\hline Bacillus subtitles & $12.0 \pm 0.91$ & $19.8 \pm 1.35$ & $36.1 \pm 2.38$ & $50.0 \pm 4.28$ \\
\hline \multicolumn{5}{|l|}{ Gram-negative (mm) } \\
\hline Pseudomonasaeruginous & $\mathrm{ND} \pm 00$ & $\mathrm{ND} \pm 00$ & $\mathrm{ND} \pm 00$ & $\mathrm{ND} \pm 00$ \\
\hline Escherichia coli & $8.5 \pm 0.53$ & $12.5 \pm 0.98$ & $30.6 \pm 2.86$ & $48.0 \pm 3.59$ \\
\hline Salmonella typhimrium & $5.9 \pm 0.28$ & $10.0 \pm 0.95$ & $19.2 \pm 1.28$ & $30.1 \pm 2.18$ \\
\hline
\end{tabular}

Values are mean and SD $(n=3)$

$\mathrm{ND}=$ not detect

The results in Table (7) indicated that using $100 \mu \mathrm{g}$ of quercetin nanoparticles had an antimicrobial impact on gram- positive and gram-negative bacteria. The highest inhibition zones was observed in grampositive bacteria Bacillus subtitles, Streptococcus aureus, and Streptococcus penoenumoia at concentrate (59.3, 43.4 and $41.7 \mathrm{~mm}$, respectively). Meanwhile, in gram-negative bacteria the highest inhibition zones at concentrate $100 \mu \mathrm{g}$ was for Escherichia coli and Salmonella Typhimurium (54.3 and $35.0 \mathrm{~mm}$, respectively). On the other hand, the quercetin nanoparticles concentrations 25, 50 and $75 \mu \mathrm{g}$ had no detected effect. While, inhibition zone was observed at $100 \mu \mathrm{g}$ of quercetin nanoparticles on Salmonella typhimrium $\quad(5.0 \mathrm{~mm}) . \quad$ Salmonella typhimurium, Escherichia coli, and
Staphylococcus aureus were selected as model bacteria due to their being food borne pathogens. The results of antimicrobial activity estimated by three various methods observed that the antimicrobial activity of quercetin nanoparticles was influential on gram-positive bacteria (Lactobacillu. monocytogenes and Staphylococcus aureus) (Arasoğlu et al., 2017).

Natural bioflavonoid is an absolutely necessary component of nutritional supplements possessing antimicrobial characteristics. The synergistic connection between nanoscience and flavonoid chemistry enhances the epidemiological characteristics of flavonoids and also reduces antimicrobial resistance through the formation of their hybrid nanocomposites and biosensing nanomaterials for flavonoids and their drug delivery (Parhi et al., 2020). 


\section{Curcumin (Curcuma longa) and quercetin nanoparticles as antimicrobial and anticancer agents}

Table (7). Effect of quercetin nanoparticles as antimicrobial agent

\begin{tabular}{|c|c|c|c|c|}
\hline \multicolumn{5}{|c|}{ Concentration $(\mu \mathrm{g})$} \\
\hline & 25 & 50 & 75 & 100 \\
\hline \multicolumn{5}{|l|}{ Gram-positive $(\mathrm{mm})$} \\
\hline Streptococcus aures & $6.4 \pm 0.61$ & $8.6 \pm 0.71$ & $18.7 \pm 1.15$ & $43.4 \pm 3.24$ \\
\hline Streptococcus penoenumoia & $10.9 \pm 0.94$ & $16.2 \pm 1.25$ & $29.2 \pm 2.04$ & $41.7 \pm 3.18$ \\
\hline Bacillus subtitles & $12.8 \pm 1.12$ & $23.2 \pm 1.97$ & $44.2 \pm 3.46$ & $59.3 \pm 4.53$ \\
\hline \multicolumn{5}{|l|}{ Gram-negative(mm) } \\
\hline Pseudomonas aeruginous & $\mathrm{ND} \pm 00$ & $\mathrm{ND} \pm 00$ & $\mathrm{ND} \pm 00$ & $5.0 \pm 0.07$ \\
\hline Escherichia coli & $10.1 \pm 0.92$ & $22.4 \pm 2.01$ & $45.0 \pm 4.21$ & $54.3 \pm 4.39$ \\
\hline Salmonella typhimrium & $11.3 \pm 1.13$ & $14.0 \pm 0.85$ & $19.2 \pm 1.53$ & $35.0 \pm 2.68$ \\
\hline
\end{tabular}

Values are mean and SD $(n=3)$

$\mathrm{ND}=$ not detect

\section{CONCLUSION}

Curcumin and quercetin nanoparticles exhibit anticancer influence against MCF-7 cells (breast cancer cell line) as well as antibacterial agents. Their role in health status may be due to the presence of bioactive compounds as natural antioxidants. It is recommended to use them in diary food as a preventative and to lower considerable side effect of cancer from chemical drugs.

\section{REFERENCES}

Abd El-Rahmanand, S.N. and Al-Jameel, S.S. (2014). Quercetin nanoparticles: Preparation and Characterization. Ind. J. Drugs, 2(3): 96-103.

Ahamefula, I.; Onwuka, G.I. and Chibuzo, N. (2014). Nutritional Composition of Tumeric (Curcuma longa) and its antimicrobial properties. Int. J. Sci. Engin. Res., 5(10):1085-1089

Alves, R.C.; Fernandes, R.P.; FonsecaSantos, B.; Victorelli, F.D. and Chorilli, M.A. (2019). Critical review of the properties and analytical methods for the determination of curcumin in biological and pharmaceutical matrices. Crit. Rev. Anal. Chem., 49:138-149.

Ananthakrishnan, P.; Balci, F.L. and Crowe, JP. (2012). Optimizing Surgical margins in breast conservation. Int. J. Surg. Oncol., 2012: $1-9$

AOAC. (2012). Official methods of analysis, $19^{\text {th }}$ edition Association of Official Analytical Chemists. Washington DC

Arasoğlu, T.; Derman, S.; Mansuroğlu, B.; Uzunoğlu, D.; Koçyiğit, B.; Gümüş, B.; Acar, T. and Tuncer, B. (2017). Preparation, characterization, and enhanced antimicrobial activity: quercetin-loaded PLGA nanoparticles against foodborne pathogens. Turk J. Biol., 41: 127-140 Bachmeier, B.; Nerlich, A.G.; Iancu, C.M.; Cilli, M.; Schleicher, E.; Vene, R.; Dell'Eva, R.; Jochum, M.; Albini, A. and Pfeffer, U. (2007). The chemopreventive polyphenol Curcumin prevents hematogenous 


\section{Safaa M. Faid}

breast cancer metastases in immunodeficient mice. Cell. Physiol. Biochem., 19:137-152.

Bachmeier, B.E.; Mohrenz, I.V.; Mirisola, V.; Schleicher, E.; Romeo, F.; Hohneke, C.; Jochum, M.; Nerlich, A.G. and Pfeffer, U. (2008). Curcumin down regulates the inflammatory cytokines CXCL1 and -2 in breast cancer cells via NFkappaB. Carcinogenesis, 29: 779789.

Bamishaiye, E.I.; Olayemi, F.F.; Awagu, E.F. and Bamshaiye, O.M. (2011). Proximate and phytochemical composition of Moringa oleifera leaves at three stages of maturation. Adv. J. Food Sci. Technol., 3(4): 233 $-237$.

Basak, P.; Adhikary, T.; Das, P. and Biswas, S. (2018). Phytochemical analysis and comparative study of antibacterial effect of turmeric extracts using different solvent. IOP Conf. Series: Materials Science and Engineering, 410: 1-8

Devadasu, V.R.; Wadsworth, R.M. and Ravi Kumar, M.N.V. (2011). Protective effects of nanoparticulate coenzyme Q10 and curcumin on inflammatory markers and lipid Metabolism in streptozotocin-induced diabetic rats: A possible remedy to diabetic complications. Drug Delivery and Translational Res., 1: 448- 455.

Eghdami, A. and Sadeghi, F. (2010). Determination of total phenolic and flavonoids contents in methanolic and aqueous extract of Achilleamil lefolium. J. Organic Chem., 2: 81-84.
Fuertes Ruitón, C.; Castro Luna, A.; Carreño, Q.R. and Arana, Á.C. (2014). Colorantes de Crcuma longa, studio de su probable efecto antiinflamatorio analgésicoantiradical libre.. Ciencia E Investigación, 1(1): 19-26.

Gomha S.M.; Salah T.A. and Abdelhamid A.O. (2015). Synthesis, characterization, and pharmacological evaluation of some novel thiadiazoles and thiazoles incorporating pyrazole moiety as anticancer agents. Mon. Chem.,146:149-158.

Gupta, S.C.; Sung, B.; Kim, J.H.; Prasad, S.; Li, S. and Aggarwal, B.B. (2013). Multitargeting by turmeric, the golden spice: From kitchen to clinic. Mol. Nutr. Food Res., 57:1510-1528

Kakran, M; Sahoo, N.G.; Li, L. and Judeh, Z. (2012). Fabrication of quercetin nanoparticles by anti-solvent precipitation method for enhanced dissolution. Powder Technol., 223: 59-64.

Kang, H.W. (2015). Antioxidant activity of ethanol and water extracts from lentil (Lens culinaris). J. Food Nutr. Res., 3(10): 667-669

Kubinarawa, D., Ajoku, G. A., Enwerem, N. M., Okorie, D. A. (2007). Preliminary phytochemical and antimicrobial screening of 50 medicinal plants from Nigeria, African Journal of Biotechnology 6(14):1690 - 1696.

Kunnumakkara, A.B.; Bordoloi, D.; Padmavathi, G.; Monisha, J.; Roy, N.K.; Prasad, S.; Aggarwal, B.B. (2017). Curcumin, the golden 


\section{Curcumin (Curcuma longa) and quercetin nanoparticles as antimicrobial and anticancer agents}

nutraceutical: Multitargeting for multiple chronic diseases. Br. J. Pharm., 174:1325-1348.

Latunde-Dada, G.O. (1980). Effect of processing on iron levels and availability on Nigeria vegetables. J. Sci. Food Agric., 53:355-361.

Li, S.; Yuan, W.; Deng, G.; Wang, P.; Yang, P. and Aggarwal, B.B. (2011). Chemical composition and product quality control of turmeric (Curcuma longa L.), Pharmaceutical Crops, 2: 28-54

Li, X.; Zhou, N.; Wang, J.; Liu, Z.; Wang, X.; Zhang, Q.; Liu, Q.; Gao, L. and Wang, R. (2018). Quercetin suppresses breast cancer stem cells (CD44+/CD24-) by inhibiting the PI3K/Akt/mTOR-signaling pathway. Life Sci., 196: 56-62,

Liu, Q.; Loo, W.T.Y.; Sze, S.C.W.; Tong, Y. (2009). Curcumin inhibits cell proliferation of MDA-MB-231 and BT-483 breast cancer cells mediated by down-regulation of $\mathrm{NF \kappa B}$, cyclinD and MMP-1 transcription. Phytomedicine, 16:916-922.

Moghtaderi, H.; Sepehri, H.; Attari, F. (2017). Combination of arabinogalactan and curcumin induces apoptosis in breast cancer cells in vitro and inhibits tumor growth via overexpression of p53 level in vivo. Biomed. Pharmacother. 2017, 88, 582-594.

Moskaug, J.; Carlsen, H.; Myhrstad, M. and Blomhoff, R. (2004). Molecular imaging of the biological effects of quercetin and quercetinrich foods.
Mechanisms of Ageing and Dev., 125(4): 315-324.

Nagahama, K.; Utsumi, T.; Kumano, T.; Maekawa, S.; Oyama, N.; Kawakami, J. (2016). Discovery of a new function of curcumin which enhances its anticancer therapeutic potency. Sci. Rep., 6:30962

Parhi, B.; Bharatiya, D. and Swain, SK. (2020). Application of quercetin flavonoid based hybrid nanocomposites: A review, Saudi Pharmaceutical J., 28:1719-1732

Qawasmeh, A., Obied, H. K., Raman, A. and Wheatley, W. (2012). Influence of fungal endophyte infection on phenolic content and antioxidant activity in grasses: Interaction between Loliumperenne and different strains of Neotyphodiumlolii. J. Agric. Food Chem., 60(13): 3381-3388.

Ramachandran, C.; Fonseca, H.B.; Jhabvala, P.; Escalon, E.A.; Melnick, S.J. (2002). Curcumin inhibits telomerase activity through human telomerase reverse transcritpase in MCF-7 breast cancer cell line. Cancer Lett. 184: 1-6.

Rauf, A.; Imran, M.; Khan, I.A.; UrRehman, M.; Gilani, S.A.; Mehmood, Z. and Mubarak, M.S.(2018). Anticancer potential of quercetin: A comprehensive review. Phytother. Res., 32: 2109-2130.

Ravichandran, K.; Ahmed, A.R.; Knorr, D.; Smetanska, I. (2012). The effect of different processing methods on phenolic acid content and antioxidant 


\section{Safaa M. Faid}

activity of red beet. Food Res. Int. 2012, 48, 16-20.

Scott, A.C. (1989). Laboratory control of antimicrobial therapy. In: Collee JG et al. eds. Practical Medical Microbiology, 13th edn. Edinburgh: Churchill Livingstone, 161-181.

Shagufta, N., Jabeen1, S., Ilya, S., Manzoor, F., Aslam, F. and Ali, A. (2010). Antibacterial activity of curcuma longa varieties against different strains of bacteria, Pak. J. Bot., 42(1): 455-462.

Shen, L. and Ji, H.F. (2012). The pharmacology of curcumin: Is it the degradation products? Trends Mol. Med., 18:138-144

Silva, F.A. and Azevedo, C.A. (2009). Principal components analysis in the software statistical assistance. 7th World Congress on Computers in Agriculture Conference Proceedings, Reno, 22-24 June 2009, 711P0409e.

Sindhu, K.; Rajaram, A.; Sreeram, K.J. and Rajaram, R.(2014). Curcumin conjugated gold nanoparticle synthesis and its biocompatibility. RSC Adv., 4:1808-1818.

Srivastava, S.; Somasagara, R.R.; Hegde, M.; Nishana, M.; Tadi, S.K.; Srivastava, M.; Choudhary, B. and Raghavan, S.C. (2016). Quercetin, a natural flavonoid interacts with DNA, arrests cell cycle and causes tumor regression by activating mitochondrial pathway of apoptosis. Sci. Rep., 6: 24049-24055

Stanojević, J.; Stanojević, L.; Cvetković, D. and Danilović, B. (2015). Chemical composition, antioxidant and antimicrobial activity of the turmeric essential oil (Curcuma longa 1.) », Advanced Technologies, 4(2): 19-25, 2015.

Sundarraj, S.; Thangam, R.; Sreevani, V.; Kaveri, K.; Gunasekaran, P.; Achiraman, S. and Kannan, S. (2012). G-sitosterol from Acacia nilotica $\mathrm{L}$. induces $\mathrm{G} 2 / \mathrm{M}$ cell cycle arrest and apoptosis through c-Myc suppression in MCF-7 and A549 cells. J. Ethnopharmacol., 14:803809

Surojanametakul, V.; $\quad$ Satmalee, P.; Saengprakai, J.; Siliwan, D. and Wattanasiritham, L. (2010). Preparación de polvo de curcuminoide de Raíz de cúrcuma (Curcuma longa Linn) para el uso de ingredientes alimenticios.. Natural Ciencia, 2010: 123-130.

Swanson, H. (2015). Flavonoids and the inflammatory response. Flavonoids, Inflammation and Cancer. World Scientific, 2015: 59-104

Tanvir, EM.; Hossen, S.; Hossain, F.; Afroz, R.; Hua, G.S.; Khalil, I. and Karim, N. (2017). Antioxidant properties of popular Turmeric (Curcuma longa) varieties from Bangladesh, J. Food Quality, 2017: 1-8

Tomeh, MA.; Hadianamrei, R. and Zhao, X. (2019). A review of curcumin and its derivatives as anticancer agents. Int. J. Mol. Sci., 20(5):1-26

Verderio, P.; Pandolfi, L.; Mazzucchelli, S.; Marinozzi, M.R.; Vanna, R.; Gramatica, F.; Corsi, F.; Colombo, M.; Morasso, C. and Prosperi, D. 


\title{
Curcumin (Curcuma longa) and quercetin nanoparticles as antimicrobial and anticancer agents
}

(2014). Antiproliferative effect of ASC-J9 delivered by PLGA nanoparticles against estrogendependent breast cancer cells. Mol. Pharm., 11: 2864-2875.

Wang, W.; Zhang, L.; Chen, T.; Guo, W.;
Bao, X.; Wang, D.; Ren, B.; Wang, H.; Li, Y. and Wang, Y. (2017). Anticancer effects of resveratrolloaded solid lipid nanoparticles on human breast cancer cells. Molecules, 22: 1814.

\section{الكركمين (كركم لونجا) وجسيمات كيرسيتين النانوية كموامل مضادة للميكروبات ومضادة للسرطان صفاء مصطفى عيد الفتاح فايد \\ قسم الاقتصاد المنزلي ، كلية التربية النوعية ، جامعة عين شمس ، عائ ، القاهرة ، مصر}

Email: dr_safaa2010@yahoo.com

\begin{abstract}
المستخلص
أجريت هذه الدراسة لتقييم النشاطات المضادة للسرطان و البكتيريا لجزيئات الكركمين و الكيرسيتين. كما تم تحديد

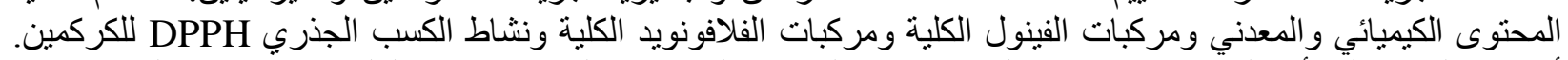

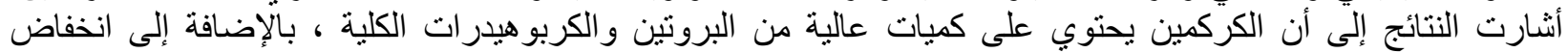

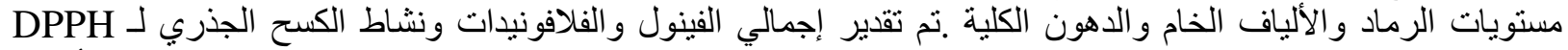

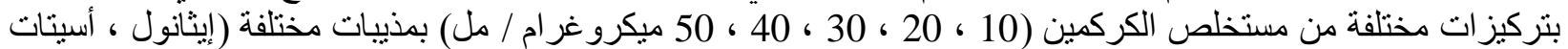

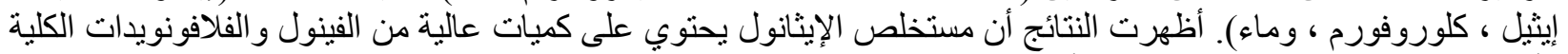

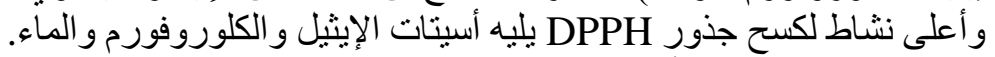

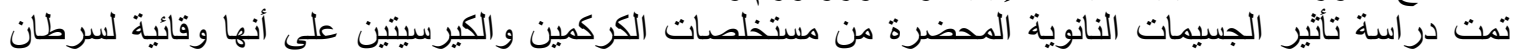

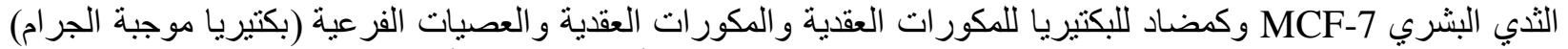

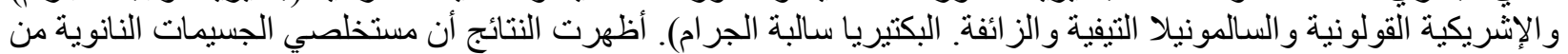

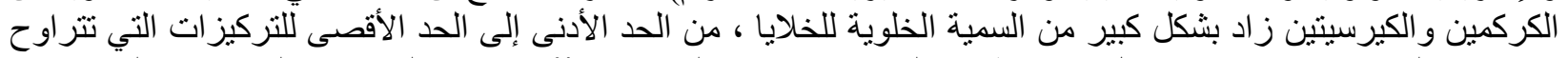

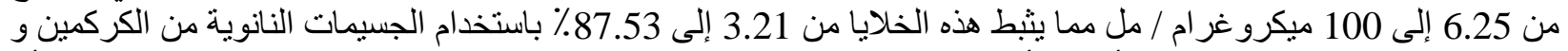

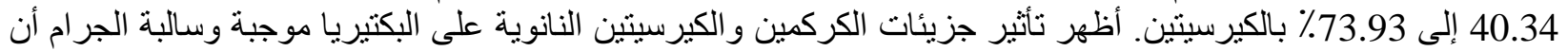

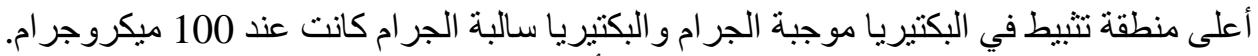

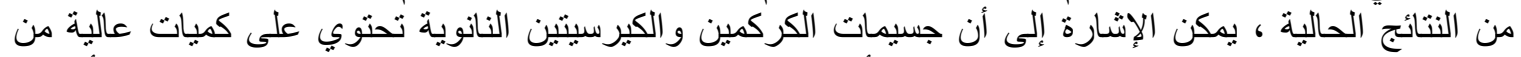

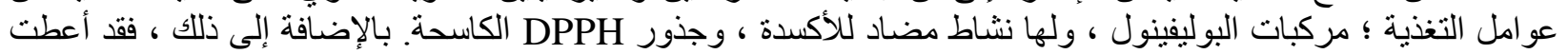

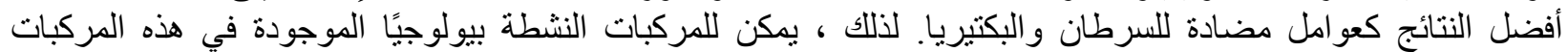

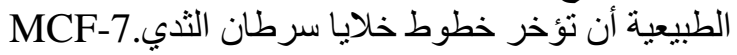

